DOI: http://doi.org/10.21698/simi.2018.fp52

\title{
QUANTIFICATION OF ANIONIC AND NONIONIC SURFACTANTS IN DOMESTIC WASTEWATER SAMPLES COLLECTED FROM ROMANIA
}

\author{
Daniel Mitru, Catalina Stoica, Mihai Nita-Lazar
}

National Research and Development Institute for Industrial Ecology-ECOIND, 71-73 Drumul Podu Dambovitei, district 6, 060652, Bucharest, mihai.nita@incdecoind.ro, Romania

\begin{abstract}
Surfactants are substances that reduce surface tension and they are worldwide used in all branches of industry such as householder products, cosmeticals, pharmaceuticals, petroleum.

The large utilization of surfactants is reflected in their accumulation in the domestic and industrial wastewaters and subsequently into the waste waster treatment plants (WWTP) and the environment. Once in the environment, the surfactants could harm it by inducing important changes in water quality which could directly affect the human life.

This paper is a monitoring study of anionic and nonionic surfactants from domestic wastewaters during three seasons (winter 2018, spring 2018 and summer 2018). The samples were taken from specific sampling points along Romanian counties: Ilfov, Prahova, Giurgiu, Dambovita and Braila.

The results showed that the concentration of the surfactants varied between 0.85 $\mathrm{mg} / \mathrm{L}$ and $6.73 \mathrm{mg} / \mathrm{L}$ for anionic surfactants and $0.81 \mathrm{mg} / \mathrm{L}$ up to $6.48 \mathrm{mg} / \mathrm{L}$ for nonionic surfactants related to the accepted value of surfactants concentration (as sum of anionic and nonionic) of $25 \mathrm{mg} / \mathrm{L}$ (Romanian legislation, HG 352/2005, NTPA 002 and Annex 2/2005). Moreover, the study revealed that the highest concentration of both anionic and nonionic surfactants were detected in Dambovita County during summer.
\end{abstract}

Keywords: anionic, nonionic, sewage, surfactants

\section{Introduction}

Surfactants or surface-active agents are substances that reduce surface tension and they have two types of functional groups in their structures: hydrophobic and hydrophilic (Mulligan 2007). The hydrophilic part remains in contact with water, while the hydrophobic part did not have any contact with the aqueous phase. The classification of surfactants relies on their ionic behaviour in solution: anionic, cationic, nonionic or amphoteric (Pereira \& Souza 2015).

Surfactants are worldwide used in all branches of industry from domestic use (household products, personal care products and pharmaceuticals) to petroleum products and. Their extensive application translated in a large production of surfactants waste represents a global environmental problem (Bosnar \& Čačić 2014). Considerable amount of surfactants are released in rivers, where they could accumulate (up to $30 \mu \mathrm{g} / \mathrm{Ls}$ ) causing serious problems inducing pollution of the aquatic systems (Odokuma \& Okpokwasili 1997). Moreover, surfactants could also accumulate in the sludge sewage treatment flow $(18.2 \mathrm{mg} / \mathrm{L}$ concentration of anionic 


\section{INTERNATIONAL SYMPOSIUM "THE ENVIRONMENT AND THE INDUSTRY", SIMI 2018, PROCEEDINGS BOOK}

surfactant measured for the influent) which could affect WWTP's treatment processes (Cserhati \& Forgacs 2002).

In the past, before 1960, the major surfactant used in the United States especially for laundry activity was propylene tetramer benzene sulphonate (PT benzene) (Scott \& Jones 2000). This chemical compound was a very resistant to degradation and accumulated in the discharged water sewages and subsequently into the environment. Due to thas situation, this surfactant was replaced with biodegradable straight alkyl surfactant chains and recently, the major anionic surfactant in use has been the linear alkylbenzene sulphonate (LAS) (Scott \&Jones 2000).

The aim of this study was to quantify the presence of anionic and nonionic surfactants in domestic wastewaters from different counties of Romania (Ilfov, Prahova, Giurgiu, Dambovita and Arges) during three seasons (winter, spring, and summer) of 2018.

Considering the fact that about $90 \%$ of the total production of synthetic surfactants comes from the sum of anionic and nonionic surfactants (Bosnar \& Čačić 2014).

\section{Materials and Methods}

The Metylene Blue Active Substances (MBAS) method was applied for the quantification of anionic surfactants. The Methylene Blue reagent was prepared according to the standard method (SR EN 903:2003). The reference used for this method was methyl ester of dodecyl benzene sulfonic acid $\left(\mathrm{C}_{19} \mathrm{H}_{32} \mathrm{O}_{33}\right.$, MDS, 99\% purity, $M=340.53 \mathrm{~g} /$ mole (Merck, Germany). The main reaction in this method was the separation between two matrix: water matrix and organic matrix. For this reaction was used chloroform (99,4\% purity) (Honeywell, USA). A buffer solution was obtained by dissolving sodium carbonate $\left(\mathrm{Na}_{2} \mathrm{CO}_{3}\right)$ and sodium hydrogen carbonate $\left(\mathrm{NaHCO}_{3}\right)$ in water and added to every sample worked to sustain the $\mathrm{pH}$. According to the standard method (ISO 7875-2:1984), the Dragendorff method was used for quantification of nonionic surfactants. The reference material used as control was nonylphenol polyethylene glycol ether $\mathrm{C}_{9} \mathrm{H}_{19} \mathrm{C}_{6} \mathrm{H}_{4}\left(\mathrm{OCH}_{2} \mathrm{CH}_{2}\right)_{9} \mathrm{OH} 99 \%$ purity, $\mathrm{M}=616.82 \mathrm{~g} / \mathrm{mole}$ (Sigma Aldrich, USA).The precipitation agent, Dragendorff reagent was made from two mixed solutions, A and B. The solution A comprise a mix between bismuth oxynitrate, glacial acetic acid and potassium iodide, and the Solution B comprise barium chloride which was dissolved in water. To complete the Dragendorff reagent, twothirds solution A with one-third solution B in volume was mixed.

The equipment used for both anionic and nonionic quantification by absorbance reading was Specord BU 205 spectrophotometer (Analytic Jena, Germany). The wavelength for detection of anionic surfactants was at $650 \mathrm{~nm}$ (using a optical cell length path of $10 \mathrm{~mm}$ and of nonionic surfactants at $263.5 \mathrm{~nm}$ (using an optical cell length path of $20 \mathrm{~mm}$ ).

The concentration of MBAS was detected by the formula:

$$
P y=\frac{A 1 x J^{2}}{V 0}
$$

where: py is masic concentration of MBAS ( $\mathrm{mg} / \mathrm{L})$;

$\mathrm{A}_{1}$ is the absorption of sample; 


\section{INTERNATIONAL SYMPOSIUM "THE ENVIRONMENT AND THE INDUSTRY", SIMI 2018, PROCEEDINGS BOOK}

$f_{2}$ is the calibration factor which was the amount of anionic surfactant represented in milligrams (it was calculated as sodium salt of dodecyl benzenesulfonate acid);

$\mathrm{V}_{0}$ is the volume was represented in milliliters.

The formula used for nonionic determination was:

$$
P y=\frac{C_{2}}{V u}
$$

Where: $\quad$ py is masic concentration of nonionic surfactants $(\mathrm{mg} / \mathrm{L})$;

$\mathrm{C}_{2}$ is the absorption of sample;

$\mathrm{V}_{0}$ is the volume was represented in milliliters.

The study was carried out during three seasons (winter 2018, spring 2018 and summer 2018) in order to identify the variation of anionic and nonionic surfactants from domestic wastewaters. The samples were taken from specific sampling points along Romanian counties: Ilfov, Prahova, Giurgiu, Dambovita and Braila.The sampling points from each county were noted: S1-Arges, S2-Dambovita, S3Prahova, S4-Giurgiu, S5-Ilfov (Figure 1).

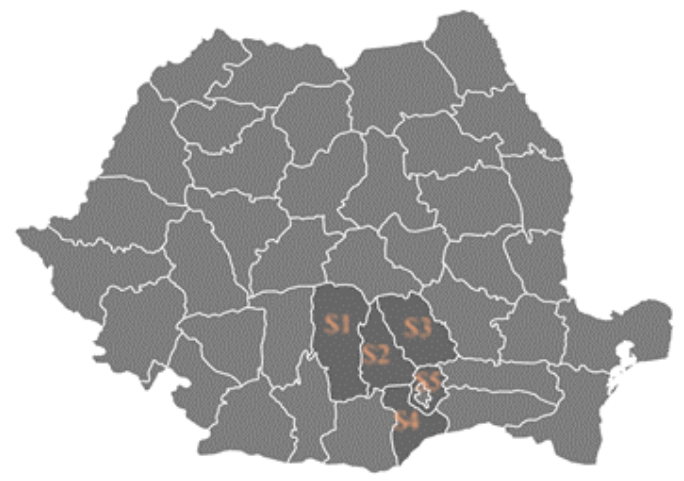

Legend

S1-Arges

S2-Dambovita

S3-Prahova

S4-Giurgiu

S5-Ilov

Figure 1. The samples points from the specific counties

\section{Results and Discussion}

The results revealed the presence of anionic surfactants in all sampling points Arges (S1), Dambovita (S2), Prahova (S3), Giurgiu (S4) and Ilfov (S5) during winter 2018 (Figure 2). Thus, the highest concentration of anionic surfactants (6.10 $\mathrm{mg} / \mathrm{L}$ ) was detected in Dambovita County (S4), while the lowest of $0.85 \mathrm{mg} / \mathrm{L}$ was in Ilfov (S5) (Figure 2a). 


\section{INTERNATIONAL SYMPOSIUM "THE ENVIRONMENT AND THE INDUSTRY", SIMI 2018, PROCEEDINGS BOOK}

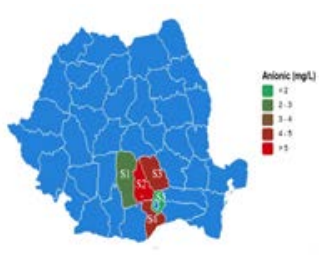

a) winter

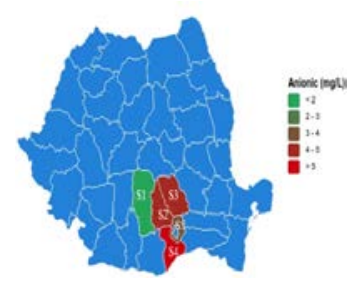

b)

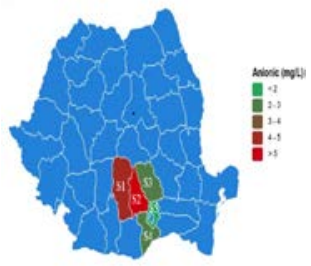

c) summer

Figure 2. The concentration of anionic surfactants detected from domestic wastewaters during study period of 2018, a) winter; b) spring; c) summer. (Color code: - surfactants concentration below $2 \mathrm{mg} / \mathrm{L}$; - surfactants concentration ranging between 2 and $3 \mathrm{mg} / \mathrm{L} ; \square$ - surfactants concentration ranging between 3 and $4 \mathrm{mg} / \mathrm{L}$; - surfactants concentration ranging between 4 and $5 \mathrm{mg} / \mathrm{L}$ and $\square$ red - surfactants concentration higher than $5 \mathrm{mg} / \mathrm{l}$ ).

In the spring season of 2018 (Figure 2b), an increase of anionic surfactants was detected in S5 sampling site $(3.75 \mathrm{mg} / \mathrm{L})$. Similar with the winter season, a lower concentration of $0.95 \mathrm{mg} / \mathrm{L}$ anionic surfactants was measured at S1 sampling site (Figure 2a).

During summer of 2018 (Figure 2c), the concentration of anionic surfactants detected from S4 and S5 sources were the highest in the all 2018 seasons (S2-6.72 $\mathrm{mg} / \mathrm{L}$ and $\mathrm{S} 1-4.33 \mathrm{mg} / \mathrm{L}$ ). The anionic surfactants concentration from the samples collected in S1, S2 and S3 sampling sites in summer year were lower (S5-1.18 $\mathrm{mg} / \mathrm{L}, \mathrm{S} 3-2.11 \mathrm{mg} / \mathrm{L}$ and $\mathrm{S} 4-2.71 \mathrm{mg} / \mathrm{L}$ than in spring.

The results of nonionic surfactants showed, in general, the same trend as in case of anionic surfactants; thus, the highest concentration $(5.64 \mathrm{mg} / \mathrm{L})$ of nonionic surfactants was detected in Dambovita County (S2), while the same County, Iflov (S5), presented the lowest concentration (0.80 mg/L) (Figure 3).

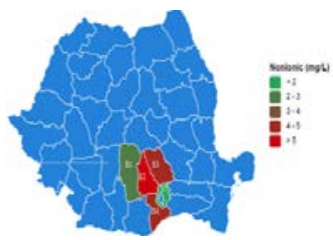

a)

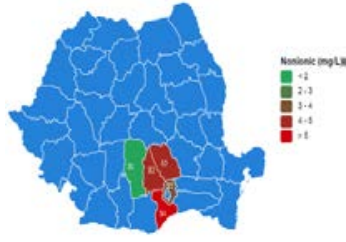

b)

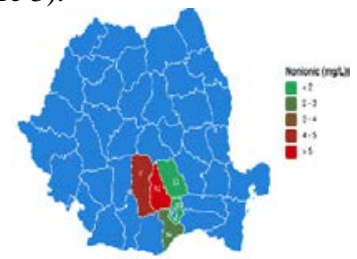

c)

summer

Figure 3. The concentration of nonionic surfactants detected from domestic wastewaters during study period of 2018, a) winter; b) spring; c) summer. (Color code: $1.18 \mathrm{mg} / \mathrm{L}$ - surfactants concentration below $2 \mathrm{mg} / \mathrm{L}$; - surfactants concentration ranging between 2 and $3 \mathrm{mg} / \mathrm{L}$; - surfactants concentration ranging between 3 and $4 \mathrm{mg} / \mathrm{L}$; - surfactants concentration ranging between 4 and $5 \mathrm{mg} / \mathrm{L}$ and $\square$ - surfactants concentration higher than $5 \mathrm{mg} / \mathrm{l}$ ). 


\section{INTERNATIONAL SYMPOSIUM "THE ENVIRONMENT AND THE INDUSTRY", SIMI 2018, PROCEEDINGS BOOK}

However, according to the national legislation (HG 352/2005, NTPA 002 and Annex 2/2005), the limit of concentration of surfactants was $25 \mathrm{mg} / \mathrm{L}$. It means that the sum of both anionic and nonionic surfactants concentration need to be less than $25 \mathrm{mg} / \mathrm{L}$ for the discharge in the sewage.

The concentration of nonionic surfactants detected in the sampling sites had the same degree of magnitude as the anionic surfactants: S5 source (3.56 mg/L) and S3 source $(0.80 \mathrm{mg} / \mathrm{L})$.

The increase of nonionic surfactants at S5 source could be linked the spring season when the weather became warm, so the domestic activities (like washing, cleaning) were growing relative to winter.

Quantification of nonionic surfactants indicated that they have the same tendency as the anionic surfactants (S2, S1 sources with increased concentration: $6.48 \mathrm{mg} / \mathrm{L}$ and $4.28 \mathrm{mg} / \mathrm{L}$ while S5, S3 and S4 sources decreased: $1.02 \mathrm{mg} / \mathrm{L}, 1.96 \mathrm{mg} / \mathrm{L}$ and 2.68 $\mathrm{mg} / \mathrm{L})$.

The nonionic surfactants were in lower presence than the anionic surfactants which means that can be a correlation between them (more anionic compounds than nonionic).

However, in every season the results showed that the wastewater sample colected from Dambovita (S2) had higher concentration of both anionic and nonionic surfactants than Ilfov, which means that in Dambovita County were more domestic activities due the superior number of population (523.730) and Ilfov 423.315). (http://www.ilfov.insse.ro/, http://www.dambovita.insse.ro/).

In addition is very important to keep under control the concentration of surfactants in domestic wastewaters; if this domestic wastewaters are undergoing to a treatment plant, high concentrations of accumulated surfactants (can inhibit sewage sludge microorganisms and compromise the way in which a wastewater treatment plant (WWTP) removes pollutants and breaks down sewage, which was the case of a Croatian study conducted on a sewage effluent where the anionic surfactant concentration was extremely high $(1090 \mathrm{mg} / \mathrm{L})$. High concentrations of surfactants means huge problems for the environment and expensive treatments in the WWTPs (Ivanković \& Hrenović 2010).

Also it is very important that the treatment plant to work properly like in the Switzerland, where the highest concentration quantified fom wastewater effluent of eleven sewage treatment plants was $2 \mathrm{mg} / \mathrm{L}$ in Basseldorf, and the lowest in Stadel with 1,1 mg/L ( Ahel \& Giger 1994).

\section{Conclusions}

The concentration of both anionic and nonionic surfactants depends on the season and also the amount of popualtion.

It was a corelation of concentration between both surfactants (anionic had higher concentration than nonionic, and when one type had increase, the other one had the same).

The importance of early quantification of domestic wastewaters means prevention before treatment. 


\section{INTERNATIONAL SYMPOSIUM "THE ENVIRONMENT AND THE INDUSTRY", SIMI 2018, PROCEEDINGS BOOK}

\section{References}

Ahel, M \& Giger, W 1994, 'Behaviour of alkylphenol polyethoxylate surfactants in the aquatic environment', Water Research, vol. 28, no. 5, pp. 1131-1142.

Bosnar, M \& Čačić, D 2014, 'Potentiometric Determination of Anionic and Nonionic Surfactants in Surface Waters and Wastewaters, The Handbook of Environmental Chemistry, Springer, Berlin, Germany, pp. 157-176.

Cserhati, T \& Forgacs, E 2002, 'Biological activity and environmental impact of anionic surfactants', Environment International, vol. 28, no. 5, pp. 337-348.

Direcţia Judeţeană de Statistică Ilfov, INS - Direcţia Judeţeană de Statistică Ilfov, 06 August 2018, Direcţia Judeţeană de Statistică Ilfov. Available from:

http://www.ilfov.insse.ro/contact/. [24 August 2018]. In Romanian.

Direcţia Judeţeană de Statistică Dambovita, INS - Direcţia Judeţeană de Statistică Dambovita, 23 August 2018, Direcţia Judeţeană de Statistică Dambovita, available from: http://www.dambovita.insse.ro/. [24 August 2018]. In Romanian.

SR EN 903:2003, Water quality - Determination of surfactants - Part 1: Determination of anionic surfactants by measurement of the methylene blue index (MBAS).

ISO 7875-2:1984, Water quality - Determination of surfactants - Part 2: Determination of non-ionic surfactants using Dragendorff reagent.

Ivanković T \& Hrenović J 2009, 'Surfactants in the environment', Arh Hig Rada Toksikol, vol. 61, pp. 95-110.

Mulligan C 2007, 'Rhamnolipid Biosurfactants', Thermodynamics, Solubility and Environmental Issues, vol 1, pp. 279-298.

Odokuma L \& Okpokwasili, G 1997, 'Seasonal Influences of the organic pollution monitoring of the new Calabar river, Nigeria', Environmental Monitoring and Assessment, vol 45, no.1, pp. 43-56.

Pereira, CL \& Souza, OA 2015, 'A perspective on the potential risks of emerging contaminants to human and environmental health', Environmental Science and Pollution Research, vol. 22, no. 18, pp. 13800-13823.

Scott, J \& Jones, N 2000, 'The biodegradation of surfactants in the environment', Biochimica et Biophysica Acta, vol. 1508, no 1-2, pp. 235-251. 